\title{
The inactivities of employer unions
}

\author{
Peter Brosnan*, Pat Walsh* and Philip Rowe**
}

This paper reports the results of a survey of New Zealand employer unions. It is found that many employer unions are completely inactive. Those that are active are little inclined to hold meetings and few provide a range of services to members. The most active employer unions are those attached to a trade association and/or with their own office separate from the New Zealand Employers Federation.

\section{Introduction}

Until the 1970s, the study of employers, their organisations and indeed management itself was a relatively neglected area in industrial relations. This was despite the vast literature in other disciplines such as sociology, psychology or management studies which examined employers in great detail. In a wide-ranging review of the study of management in British industrial relations, Wood (1982) focussed upon this neglect and evaluated 4 general reasons which were often put forward to explain it. He dismissed as naive the belief that to study employers is to be seen as supporting them, and as untrue the argument that employer suspicion of academic research makes it more difficult to get access to data that when studying trade unions (Wood, 1982, p. 52).

Wood laid more stress upon 2 other reasons, both of them connected with the development of industrial relations as an academic discipline. The pioneers were scholars in industrial relations who were sympathetic to the early struggles of trade unions and thus focussed their attention on unions. As unions gradually won their battles for existence, however, the emphasis shifted away from studying institutions per se to the emerging relations between unions and employers, and especially the operation of collective bargaining procedures. As a result, the study of employers themselves never took centre stage in the discipline. Wood argued that the continued neglect of employers in later years stemmed from the acceptance by subsequent generations of industrial relations researchers of the dominant values of capitalist societies. Trade unions were seen as a problem, as something that required explanation, and - it might be added - in many cases as muchmaligned institutions in need of defence. In contrast, management and employers were, for the most part, not seen in this way. Instead, they tended to enter the picture largely because of their relations with unions and governments, and not as subjects for study in their own right.

In the 1970 s, these attitudes changed quite dramatically. In the United Kingdom

\footnotetext{
* Senior Lecturer in Industrial Relations, Victoria University of Wellington.

**Sydney, Australia
}

This research was made possible by Victoria University of Wellington Internal Research Grant No. $167 / 82$. The authors acknowledge the assistance of the numerous union secretaries who completed the questionnaires and took part in subsequent discussions. Special thanks are due to the following for their advice, B Greenslade, S Marshall, J Rowe, D Stewart, R Taylor, J McCarthy and N West. 
the stimulus to change was the emergence of a widely held belief that management was an issue for industrial relations researchers, and that it could no longer be taken as a given needing no explanation. The report of the Donovan Royal Commission (1968) contributed greatly to the development of these new perceptions of the role of employers and management in industrial relations. The Donovan Commission laid a substantial portion of the blame for the swift development in the 1960s of the "informal" system of industrial relations and the associated fragmentation of the formal system at the door of management:

Unofficial strikes are above all the result of the inadequate conduct of industrial relations at company and plant level. They will persist so long as companies pay inadequate attention to their pay structures and personnel policies, and the methods of negotiation adopted at the workplace remain in their present chaotic state (Donovan, 1968, p. 121).

The Royal Commission's recommendation that British employers move to develop coherent company level industrial relations and personnel policies made the role of employers in industrial relations an issue of public policy. The Heath Government's Industrial Relations Act, 1971, may be seen as a vain effort to construct a framework that would encourage the development of these new managerial industrial relations policies (Moran, 1977). The extraordinary outcomes of that ill fated legislation helped to turn the role of employers into an increasingly important issue in industrial relations research (McCarthy and Ellis, 1973). This trend subsequently received a further boost by a second major report on British industrial relations, that of the Bullock Committee of Inquiry on Industrial Democracy (Bullock, 1977). As Winchester observes, the debate over the Bullock Report focussed widespread attention upon the key strategic role in industrial relations of employers, particularly through its recommendation that worker directors be established to give employees participation in major strategic decisions (Winchester, 1983, p. 107). Given the controversial nature of the Bullock recommendations, it is not surprising that experiments in industrial democracy, and the impact they had on management strategy gave rise to considerable research (Brannen et al., 1976; Chiplin et al., 1977; and Batstone et al., 1983).

Within this rapidly developing area of research into management and employers, 2 broad approaches can be identified. The first approach is to examine the strategic choices made by management in their pursuit of control in industrial relations. These strategic choices take place at 2 levels, at the workplace and in the wider corporate setting. There is already a substantial literature dealing with management strategies in the workplace, and the particular patterns of worker resistance which result (Batstone et al., 1977, 1978; Brown, 1981; Purcell, 1981; Edwards and Sullion, 1982). For the most part this literature has been UK based, whereas the analysis of management strategy in the wider corporate setting draws on both American and British research (Timperley, 1980; Purcell, 1983; Thurley and Wood, 1983; Kochan, McKersie and Cappelli, 1984; Cappelli, 1985). This research has been highly innovative and very challenging for the discipline of industrial relations. It argues that industrial relations decisions are just one component of a wider corporate strategy and can only be understood in terms of their relationship with financial, production marketing and all other corporate considerations. This approach redefines what industrial relations is and implies radical change to the subject matter of industrial relations research.

The second broad approach to the study of management in industrial relations is to study employers' organisations. However, this area of research is still not well developed. This is despite Clegg's argument that the collective bargaining system in any country is strongly influenced by the structure and attitudes of employers' associations and management (1976, p. 10). Much less is known about employer organisations than about worker unions, although in recent years there have been efforts to remedy this (Jackson and Sisson, 1976; Sisson, 1977, 1983; Plowman, 1978), and 1984 saw the publication of a comparative study of employers' associations in 10 countries (Windmuller and Gladstone, 1984).

All the preceding comments concerning the neglect of employers in industrial relations 
research apply forcefully to New Zealand. Other than their inclusion in general studies of industrial relations, employers have scarcely been studied at all. The only analysis of any substance has been by Rudman (1974). To follow the approach of studying the strategic industrial relations decisions of individual companies would require a largescale commitment of research funds, which, so far at least, has not been forthcoming in New Zealand. However, it has been possible to follow the second broad approach, namely to study employer associations. In 1982-83, 2 surveys were conducted of employer unions and associations. In this article we report on some of the results of those surveys.

\section{Employer organisations in New Zealand}

As with worker unions, the development of employer unions in New Zealand has been heavily influenced by the provisions of industrial legislation. The major impetus to the growth of employer unions has been the enactment of legislation to further the growth and activities of trade unions. There have been 2 stages to this. The first employer associations, formed after the Maritime Strike, fell into decline in the 1890 s but were revived in the early 1900s once the effects of the 1894 Industrial Conciliation and Arbitration Act began to make themselves felt. Between 1901 and 1911 the number of registered employer unions grew from 68 to 118 , while total membership more than doubled from 1824 to 4251 (Rudman, 1974, p. 70). The sudden growth in employer unions was a direct result of the recovery of worker unions under the protection of the arbitration system, and the need for employers to be represented in conciliation proceedings and before the Arbitration Court.

The second phase of employer union development followed the restoration of compulsory arbitration and the introduction of compulsory membership of trade unions in 1936. The situation had altered very little between 1911 and 1935, with the number of unions rising from 118 to 131 and total membership from 4251 to 4344 . However, with worker unions granted complete jurisdiction over all industries and occupations, and with automatic access to the Arbitration Court, thousands of employers who had previously enjoyed a union-free existence hastened to join or, if necessary, to form an employer union. Between 1935 and 1937 the number of employer unions increased to 239 and total membership to 8441 (Rudman, 1974, p. 70). Since then, the number of unions has been fairly stable, while total membership has of course risen steadily. At 31 December 1984, there were 15 employer associations and 222 employer unions, with the total union membership being 39771 (Department of Labour, 1985, pp. 83-88).

Various employer unions are affiliated to the New Zealand Employers' Federation (NZEF) - the central organisation of employers - either directly or through one of the federation's regional divisions. The NZEF was established in 1902 to coordinate the response of employers to the growth of worker unions after the passage of the Industrial Conciliation and Arbitration Act. The NZEF acts as the representative of employers in dealings with the Government and in any General Wage Order hearings. It also provides research and advisory services to its members. The most important service offered by the NZEF has been the provision of advocates to represent employer unions in award negotiations, and to assist in other disputes. The staff of the NZEF in fact administer many employer unions directly from their own office. We will explore this relationship below.

The NZEF has become increasingly important during the last 20 years. To a large extent, this has followed inevitably from the rising level of government intervention in the industrial relations system. The NZEF has been required to deal with the Government on a continual basis and to represent employers in key bipartite and tripartite negotiations. A further reason for the increased importance of the NZEF has been the growing need for it to coordinate employers' wage bargaining policies as a consequence of the more fragmented bargaining system that has prevailed since the 1960s (Walsh, 1984a). In response to these and other considerations, the NZEF underwent major structural reform in the early 1970s. The reform was initiated principally by the Manufacturers Federation which, 


\section{Brosnan, Walsh and Rowe}

along with other employer organisations felt the NZEF was not effectively representing their interests (Rudman, 1974, p. 72). The reforms gave representation on the NZEF National Executive to the Manufacturers Federation, the Chamber of Commerce and Federated Farmers, as well as to other specified employer sectors. These changes helped resolve the sometimes difficult relationship between the NZEF and other peak employer organisations.

The central role of the NZEF, especially in wage negotiations, raises the question of what it is that employer unions do. Certainly, they have never been viewed as a highly active or dynamic component of the industrial relations system. As we shall see, a great many are not independent organisations in their own right, but are attached to the NZEF (or 1 of its 4 regional divisions) or to a trade association. Indeed, Rudman describes them as "shadow" organisations (1974, p. 68). Nonetheless, they have existed for almost 100 years and they carry out functions of great importance to their members and to worker unions, for without an appropriate employer union, creating a dispute of interest to obtain an award and its blanket coverage is more difficult. Yet, very little is known about them. In this article we hope to cast some light on the activities of the registered employer unions.

Our analysis below is restricted to employer unions registered under the Industrial Relations Act. However, we do acknowledge that there are some employer unions which operate despite not being registered. The Bankers Association is one of these. Another, which we refer to below, is the National Association of Retail Grocers and Supermarkets (NARGON). There are possibly others but we have no satisfactory method of identifying these organisations.

\section{The surveys}

The structure of the surveys was complicated in that most industrial unions of employers (IUOEs) do not operate independently. Some operate out of the same office as a trade association. These we term bifunctional unions. Some operate out of the New Zealand Employers Federation (NZEF) offices or from the office of one of the regional associations. Furthermore, some unions are federated into industrial associations of employers (IAOEs). This last fact produced an additional complication in that it was not obvious which body should be regarded as the principal organisation. There were 13 of these IAOEs at the time of the survey. ${ }^{1}$ They were all industry-based and together they affiliated 105 IUOEs. It was clear from the outset that, in at least some cases, the IAOE was the effective organisation and that the constituent IUOEs were merely the means by which individual employers could belong to the IAOE.

Accordingly, it was decided to conduct 2 surveys; the first covered those IUOEs which belonged to IAOEs and the second centred on IAOEs and unaffiliated IUOEs. The 2 surveys were similarly structured in that each IUOE or IAOE was sent 2 questionnaires and a covering sheet which asked "Does your union have a parallel trade association operating out of the same premises?". If the answer was "yes", they were asked to fill in the longer of the 2 questionnaires and which included questions about the relationship between the IUOE or IAOE and the trade association. If the answer was "no", the simpler questionnaire was completed. The 2 questionnaires in the first survey were slightly longer again since they had additional questions on the relationship between the IUOE and its IAOE.

The surveys were conducted by mail mainly during 1982-1983 and every IUOE and IAOE registered at 31 December 1981 was sent the relevant questionnaires. Follow-up

1 A fourteenth IAOE, the New Zealand Association of Waterfront Employers was registered on 1 July 1982. However, we based our survey on the list of unions in the Department of Labour's Annual Report to March 1982 and thus we did not survey that IAOE. Instead, we surveyed the 2 IUOEs which belonged to it. See infra. 
letters and questionnaires were sent to those organisations which did not reply to the initial mail-out. If this still did not produce a reply, a third letter and set of questionnaires was sent and followed up, where possible, with a phone call.

\section{The first survey : IUOEs affiliated to IAOEs}

The final response rates to the first survey are given in Table 1 . Table 2 gives the response rates to the second survey. It will be seen that the first survey had a much lower response rate than the second. The response rate to the first survey, in terms of IUOEs, was 54.7 percent. In terms of member firms, the response rate was 57.7 percent. In contrast, the second survey had a virtually complete response. As Table 2 shows, 97.6 percent of all IAOEs and unaffiliated IUOEs responded and between them they directly or indirectly represented 99.7 percent of all members of registered employer unions.

Table 1 : Coverage of first survey and distribution of respondents

\begin{tabular}{|c|c|c|c|c|c|c|}
\hline \multirow[b]{2}{*}{ Location of office } & \multicolumn{2}{|c|}{ Active } & \multicolumn{2}{|c|}{ Inactive } & \multicolumn{2}{|c|}{ Total } \\
\hline & IUOEs & $\begin{array}{l}\text { Member } \\
\text { firms }\end{array}$ & IUOEs & $\begin{array}{l}\text { Member } \\
\text { firms }\end{array}$ & IUOEs & $\begin{array}{l}\text { Member } \\
\text { firms }\end{array}$ \\
\hline \multicolumn{7}{|c|}{ With trade association } \\
\hline At NZEF & 4 & 297 & 1 & 225 & 5 & 522 \\
\hline Not at NZEF & 24 & 1431 & 6 & 303 & 30 & 1734 \\
\hline \multicolumn{7}{|c|}{ Not with trade association } \\
\hline At NZEF & 2 & 51 & 3 & 32 & 5 & 83 \\
\hline Not at NZEF & 13 & 738 & 5 & 63 & 18 & 801 \\
\hline Subtotal & 43 & 2517 & 15 & 623 & 58 & 3140 \\
\hline No reply & & & & & 48 & 2302 \\
\hline Total & & & & & 106 & 5442 \\
\hline
\end{tabular}

Table 2 : Coverage of second survey and distribution of respondents

\begin{tabular}{|c|c|c|c|c|c|c|c|}
\hline \multirow[b]{2}{*}{ Location of office } & \multicolumn{3}{|c|}{ Active } & \multicolumn{2}{|c|}{ Inactive } & \multicolumn{2}{|c|}{ Total } \\
\hline & IAOEs & $\begin{array}{l}\text { Unaffiliated } \\
\text { IUOEs }\end{array}$ & $\begin{array}{l}\text { Member } \\
\text { firms }\end{array}$ & $\begin{array}{l}\text { Unaffiliated } \\
\text { IUOEs }\end{array}$ & $\begin{array}{l}\text { Member } \\
\text { firms }\end{array}$ & $\begin{array}{l}\text { IAOEs } \\
\text { and } \\
\text { IUOEs }\end{array}$ & $\begin{array}{c}\text { Member } \\
\text { firms }\end{array}$ \\
\hline
\end{tabular}

With trade

association

$\begin{array}{lrrrrrrr}\text { At NZEF } & 1 & 6 & 1063 & 1 & 203 & 8 & 1266 \\ \text { Not at NZEF } & 7 & 45 & 22292 & 7 & 1366 & 59 & 23658\end{array}$

Not with

trade association

$\begin{array}{lrrrrrrr}\text { At NZEF } & 4 & 26 & 6008 & 4 & 44 & 34 & 6052 \\ \text { Not at NZEF } & 1 & 14 & 2936 & 6 & 292 & 21 & 3228 \\ \text { total } & 13 & 91 & 32299 & 18 & 1905 & 122 & 34204 \\ \text { reply } & & & & & & 3 & 115 \\ \text { al } & & & & & & 125 & 34319\end{array}$


At first sight, the difference in response rates to the 2 surveys is rather surprising. When we examine the results of the first survey, however, we find that most IUOEs which are affiliated to IAOEs have practically no life of their own. As Table 1 shows, 15 of the 58 IUOEs which replied to the survey were completely inactive. Virtually all of the remaining 43 indicated low levels of activity. Fifteen (not necessarily the same 15 who were completely inactive) of the responding IUOEs claimed not to take part in award negotiations and only 3 took part in negotiations independently of the IAOE to which they were affiliated. Perhaps coincidentally, these 3 were all located in the OtagoSouthland area. A common response was that the IUOE existed to provide an information flow of local views to the IAOE and/or to produce a local assessor for the IAOE's award negotiations. There were some IUOEs which provided advice to members and a small number offered a range of services. Outside of some involvement in the IAOE's award negotiations, the only other significant sign of local activity was involvement in apprenticeship matters and representation on apprenticeship committees.

The replies indicated that many regarded themselves as sleeping organisations. Typical comments were: "The IUOE is not operative. We rely on the association" or, "We exist only in case there is a local dispute but there has not been one for many years" or, "We are only a paper organisation" or again, "We meet only in emergencies" or, "The union holds no funds". One IUOE responded "We have been trying for many years to have the union dissolved".

It was clear in many cases that the IUOE secretary had virtually no knowledge of industrial matters. Some even required convincing that we were interested in the employers' union rather than the workers' union. This lack of industrial orientation was obvious from some questionnaires, while, in other cases, the secretary contacted us by telephone and confessed his or her lack of knowledge or involvement in industrial matters. In some cases the secretaries were public accountants who merely acted as a post office for the IUOE. In some other cases the secretary sent the questionnaires to the IAOE for completion.

In general, the IUOEs were such artificial organisations that it was difficult for the secretaries of bifunctional IUOEs to distinguish the separate legal existence of the IUOE and the trade association from whose premises it operated. This difficulty was so great that we suspect that some of the IUOEs counted in the first colum of Table 1 as not having a parallel trade association did have one but that the secretaries interpreted the question as meaning a second trade association beyond the one which shadowed the IUOE.

As far as the 35 which claimed to be bifunctional are concerned, the subordinate nature of the IUOE was very plain. In nearly every case, the trade association officers held equivalent positions in the IUOE. A number of responding secretaries felt the need to point out that the IUOE meetings were held in conjunction with the trade association's. In some cases, they were held immediately afterwards and lasted for periods of 3-10 minutes. In other cases, they were held simultaneously with 2 minute books and some matters being entered as trade association minutes and some as IUOE minutes. It was certainly clear that trade association matters dominated the meetings. Despite this however, one secretary commented that the "IUOE is used at the moment as a debt collecting agency to gather in the fees owing to" the trade association. What he meant was that the possibility of worker union activity was used as a threat to coerce employers into joining the IUOE through membership of the trade association.

This is not to say that there were no IUOEs which appeared quite active. Not surprisingly, the most active were those which were not at the NZEF. Often these were regional branches of trade associations such as the Hotel Association of New Zealand or Master builders, plumbers or painters. Some of these IUOEs appeared to handle local disputes without reference to the IAOE and claimed to offer advice and other assistance to members. It was also of interest to note that the level of local activity varied among the IUOEs affiliated to the same IAOE. In general, the larger IUOEs were more active but this was not always so and it appeared that the competence of the secretary may have been 
a factor determining the level of activity of individual IUOEs.

What of the 48 IUOEs which did not reply to our survey? Given the contrasting levels of response to our 2 surveys and the low level of activity which generally prevailed among respondents to the first survey (not to mention the ignorance of industrial matters by many secretaries), it seems reasonable to assume that the level of activity among nonresponding IUOEs would be as low as among responding IUOEs but, in all probability, a good deal lower. In view of the low level of response and of activity among IUOEs affiliated to LAOEs, we decided to treat the IAOE as the effective union for the purposes of analysis and to concentrate on the results of the second survey. In the analysis which follows, we shall refer to IUOEs and IAOEs collectively as "unions" or "employer unions".

\section{The second survey : IAOEs and unaffiliated IUOEs}

As we noted above, the second survey covered all IAOEs and IUOEs which did not belong to an IAOE. We refer to these collectively as "unions". The distribution of these unions is given by Table 2. Compared with the IUOEs responding to the first survey, we note that the independent IUOEs are more likely to be located at the NZEF but marginally less likely to be at the same address as a trade association (bifunctional unions). One half are bifunctional and roughly one third are at the NZEF. They are also much more likely to be active. All 13 IAOEs were active and 91 out of 112 unaffiliated IUOEs were definitely active (compared with 43 out of 106 affiliated IUOEs).

\section{Administrative location}

Table 2 reveals a complicated relationship among employer unions, the NZEF and its regional divisions and the various trade associations. Indeed, from Table 2, we can see that employer organisations fall into 4 categories. The largest category are those bifunctional unions not at the NZEF (or one of its regional divisions). These comprise 59 of the 122 unions which replied to our second survey. The second largest category (34 of 122) were single function unions whose office was at the NZEF. There were 21 organisations in the third category, those single function unions whose offices were separate from the NZEF, and, finally, 8 bifunctional unions who were located at the NZEF. Organisational size seems to be a factor in accounting for this distribution. The smaller the employer union, the more likely it is to be attached to the NZEF. On average, NZEF-based unions are only half the size of the remainder. Similarly, the average membership of bifunctional unions is twice the size of single function unions.

The pattern in Table 2 (and Table 1) highlights the different nature of New Zealand's worker unions and employer unions, despite the virtually identical legislation under which they operate and the many similar functions they perform. Although a great many worker unions are very limited in their resources and capacities, they do at least retain an independent life of their own. No worker union is run directly by the FOL or its district regional councils. Even the phenomenon of multiple union secretaryships is in decline. By contrast, the vast bulk of employer unions are run by a trade association or the NZEF, with only 21 respondents claiming to be independent of both. On closer inspection, however, even this limited sign of independent employer unions proves misleading. Six were inactive - a higher proportion than any other category. Very few of the other 15 were significant organisations. Four were unions for lawyers or accountants, while others included unions representing relatively minor employer groups such as the Dunedin Master Tailors, the Canterbury Master Plasterers and the Wellington Provincial Tobacconists and Registered Hairdressers. Indeed, according to the responses to our survey, there are only 4 registered employer unions of major importance operating independently of the NZEF or a trade association. These are the employer unions in the pulp and paper and cleaning industries, on the waterfront and amongst retail butchers.

At first sight, the location of so many employer organisations at a trade association - 
what we term bifunctional organisations - may seem surprising. Although it is by no means unknown in other countries for one organisation to embrace both roles, the distinction between employers' trade and industrial relations interests has tended in other countries to lead to the formation of 2 different organisations. Windmuller $(1984$, p. 2) points out that this "organisational dualism" allowed employers to choose whether to cooperate with others on either trade or industrial matters, while retaining autonomy in the other area. It also ensured that wider economic issues remained the province of the trade rather than the employer association, thus helping to keep those issues out of the industrial sphere. However, these reasons for preserving the trade and employer associations as separate organisations were not as relevant in New Zealand as elsewhere. Historically, under the blanket coverage award system, there was little incentive for individual employers to retain autonomy in industrial relations, regardless of whether they cooperated in trade matters. Indeed, as the case noted earlier highlighted, trade associations are able to exploit the importance of being represented in award negotiations to persuade employers to join. Secondly, the narrow definition of "industrial matters" prevented trade unions from intruding into wider trade and economic questions. Consequently, there was not the same need in New Zealand as in other countries for separate trade and employer associations (cf. Rudman, 1974, p. 69).

As well as these, there are advantages to employers in merging their trade and industrial relations organisations. The most obvious advantage is the cost-saving involved. Indeed, Windmuller suggests that economies of scale may be a factor in an emerging trend in some countries towards the amalgamation of trade and employer associations (Windmuller, 1984 , p. 8). The merging of the 2 organisations also enables both trade and industrial relations considerations to be taken into account in employer decisions and public statements. This means that the knowledge and experience of employers in a particular occupation or industry can be brought to bear upon industrial relations issues through their trade association. In addition, the permanent staff of the trade association can apply their own specialised expertise to the problems of industrial relations.

One major implication of the widespread merging of trade associations and employer organisations in New Zealand is that it allows an alternative perspective to that of the NZEF to be heard in employer circles. Since very few employer groups are able to maintain a genuinely independent industrial relations organisation, their choice essentially is whether they wish the activities of their employer union to be carried out by a trade association or by the NZEF. Although there were 7 bifunctional IUOEs and 1 bifunctional IAOE located at the NAEF, in the vast majority of cases the location of an employer union at a trade association ensured it remained detached from the NZEF. This did not mean it escaped the influence of the federation entirely. As we shall see below, almost all employer organisations use the services of a federation advocate. Many also call on the NZEF for advice on other matters including the selection of its own assessors in award negotiations.

The separation of bifunctional unions from the NZEF has prevented the development of a federation monopoly over the industrial relations organisation of New Zealand's employers, a monopoly which the federation may view as a mixed blessing. It has also ensured the presentation of alternative views and policies, informed by a deeper understanding of the industry or occupation concerned than could usually be offered by a member of the NZEF staff. It may also, in exceptional circumstances, allow a particular group of employers to prevail in a conflict of views with the NZEF, as happened in 1985 during the negotiation of the electrical contractors' award. Other recent examples would include the negotiation of the drivers' award in 1979 (which sparked the first threatened use of the Remuneration Act and led directly to the General Strike) (Walsh and McMaster, 1980), and the introduction over NZEF opposition of various qualification payments for tradespeople, especially in the engineering and electrical industries during the 1970 s (Walsh, 1984b). 


\section{Inactive IUOEs}

The second survey found 18 IUOEs which were inactive in the sense of not being involved in award negotiations and not providing services to members. Although these inactive IUOEs comprise 14 percent of all IAOEs, they represent only 6 percent of member firms. These inactive IUOEs can be divided into 4 groups. Two groups while nominally inactive were not really so. The first group comprised only one IUOE, the New Zealand Municipalities IUOE. This organisation was registered early in 1982 and, when contacted, had not yet been involved in negotiations but it clearly intended to do so.

The second group comprised 8 grocery IUOEs. These IUOEs stated that they were represented in negotiations by the National Association of Retail Grocers and Supermarkets of New Zealand Inc. (NARGON). NARGON clearly fills the role of an IAOE but, since it is not registered as such the individual IUOEs or supermarkets are nominally the respondents in award proceedings. Although NARGON completed our questionnaire, their responses are not included in the tables which follow. It is clear from its replies, however, that NARGON is one of the more active employer unions.

The third group of inactive IUOEs comprised 3 that declared themselves to be defunct. One of these, the Northern Steamship Company, is now in the process of having its registration cancelled. The other 2, however, did submit returns for 1984 to the Department of Labour.

The fourth group comprised 6 IUOEs that were not active currently but kept their organisation registered in case it should be required in the future. An interesting illustration of this is found in the reply of one of these organisations, the North Canterbury American Type Threshing Mill and Header Harvester Owners IUOE. They replied that their organisation had been formed in the mid-1920s when the English wooden threshing mills had been replaced by the American type. The English type had been owned by contractors but the American type were owned by farmers. The IUOE was formed in case the farm employees who operated the mills became unionised. Although the latter has still not happened, the IUOE is kept in place in case unionisation does occur.

As for the 3 IUOEs who did not reply, we cannot be sure whether they are active or not. Information obtained from the Department of Labour indicated that in 2 cases, the secretary was probably the wife of a member. In the other case, also, the secretary appeared to be a part timer. In view of this, and the fact that none of the 3 IUOEs was cited in an award, it seems reasonable to conclude that these 3 IUOEs are inactive too.

The remaining 104 unions appeared to be active. There were 4 however which, while holding meetings and/or providing services to members, did not take part in negotiations. One of these was the Auckland Chain Grocers IUOE. Like the other grocers' IUOEs referred to above, its award was negotiated by NARGON but the IUOE did hold meetings and provide some services to members. As far as the other IUOEs were concerned, the New Zealand Tyre Manufacturers IAOE, stated that its role was only one of coordination. Each member company was registered as an IUOE and negotiated separately. One of the others was located at the NZEF but appeared to be virtually nothing. The remaining IUOE was located at the offices of a member and, although meetings were held, they appeared to be mainly concerned with trade association matters such as the prices of materials. They did also deal with apprenticeship matters, however, so we did not classify them as inactive. Data relating to these 4 unions are included in the tables that follow.

Low levels of activity were discernable in many other cases. The secretaries of these unions admitted frankly that their union was no more than a legal entity set up as a virtual requirement of the Industrial Relations Act.

\section{Activity}

A variety of measures could be used to assess the level of activity of employer unions. In this paper, we use 3 broad measures which were obtained from the questionnaire results: the union's bargaining arrangements, the frequency of meetings and the services provided 
to members. We chose not to rely on other measures such as whether the union was cited in an award since section 68(5) of the Industrial Relations Act requires that an IUOE or IAOE be cited automatically as a respondent to an award whether or not it took part in the relevant negotiations. In fact, the only clue to an employer unions involvement obtainable from the Book of Awards is those rare cases where the employer union is the only respondent.

\section{Use of NZEF advocates}

Our measures of activity of employer unions are provided by the data in Tables 3 to 7. The first of these, Table 3 , shows the heavy reliance of employer unions on the NZEF. Ninety two percent of responding unions report that they use the advocacy services of the NZEF. Needless to say, those located at the NZEF all use NZEF advocates but it is interesting that 90 percent of the bifunctional unions separate from the NZEF also use the NZEF advocacy services. As it turns out, the organisations least likely to use NZEF advocates are unions with premises entirely of their own. Nonetheless, even this group had strong links to the NZEF in many respects. Eleven out of the 15 report using NZEF advocates and they get NZEF advice when it is needed. These figures show very clearly how centralised award bargaining is on the employers' side. Of course the use of an NZEF advocate does not automatically give the federation complete control over an organisation's negotiating stance, since the advocate must accept instructions from those he or she represents. There have been occasions on which those instructions differ substantially from the NZEF's preferred position. This was sharply illustrated by the negotiation of the 1985 electrical contractors' award referred to above. But such instances are the exception, and there can be no doubting that the near monopoly of NZEF advocates gives the federation considerable control over the employers' position in wage negotiations. This contrasts most markedly with the minimal role played in wage negotiations by the FOL.

Those unions which negotiate without NZEF advocates belong to certain industries; the waterfront, the meat industry and the timber and woodpulp industries. Somewhat surprisingly, 2 lesser known unions, the New Zealand Sign Trades IUOE and the Canterbury Master Plasterers IUOE, claim to have their own secretaries act as their advocates rather than NZEF staff. Some of the larger bifunctional unions which do use the NZEF, nonetheless do retain industrial staff who handle a range of issues independently of the NZEF. These are explored below (see Table 7).

\section{Meetings}

A strong indicator of activity among employer unions is the frequency of meetings. Data on these are provided in Tables 4 and 5 . We determine from Table 4 that only one half of employer unions hold meetings of members outside of award time and Table 5 reveals that 30 percent of unions do not even have meetings of their industrial or management committees outside of award time. Again we find the most activity for unions which are located away from the NZEF or which are bifunctional. Location away from the NZEF is the more important variable. Those away from the NZEF are twice as likely to have meetings of members and of the industrial/management committee than NZEF unions. Bifunctional unions are half as likely again than single function unions to have meetings outside award time. Thus the holding of meetings is most common for those unions which are both located away from the NZEF and are bifunctional organisations. These comprise one half of employer unions, and two thirds report having membership meetings outside award time, and 9 out of 10 report industrial or management committee meetings outside award times. Several of these unions reported monthly meetings of their industrial or management committee.

We must be careful in interpreting these figures. We note below that NZEF-based and single function unions take a less reactive bargaining stance. Importantly, as we noted 
Table 3 : Use of advocacy services of New Zealand Employers Federation

\begin{tabular}{lcccr}
\hline & Office at NZEF & \multicolumn{2}{c}{ Office not at NZEF } & Total \\
\cline { 3 - 4 } & & $\begin{array}{c}\text { At trade } \\
\text { Association }\end{array}$ & $\begin{array}{c}\text { Not at trade } \\
\text { Association }\end{array}$ & \\
\hline Use services & 34 & 47 & 11 & 92 \\
Do not use services & 0 & 5 & 3 & 8 \\
Not stated & 3 & 0 & 1 & 4 \\
Total & 37 & 52 & 15 & 104 \\
\hline
\end{tabular}

Table 4: Meetings of members other than at award negotiation time

\begin{tabular}{lccccrr}
\hline & \multicolumn{2}{c}{ Trade association } & & Not trade association & Total \\
\cline { 2 - 3 } & At NZEF & $\begin{array}{c}\text { Not at } \\
\text { NZEF }\end{array}$ & At NZEF & $\begin{array}{c}\text { Not at } \\
\text { NZEF }\end{array}$ & \\
\hline Meetings held outside of award time & 1 & 34 & 9 & 8 & 52 \\
Meetings not held outside of award time & 5 & 17 & 18 & 6 & 46 \\
Not stated & 1 & 1 & 3 & 1 & 6 \\
Total & 7 & 52 & 30 & 15 & 104 \\
\hline
\end{tabular}

Table 5: Meetings of industrial/management committee other than at award negotiation. time

\begin{tabular}{lcccccr}
\hline & \multicolumn{2}{c}{ Trade association } & & Not trade association & Total \\
\cline { 2 - 3 } & At NZEF & $\begin{array}{c}\text { Not at } \\
\text { NZEF }\end{array}$ & At NZEF & $\begin{array}{c}\text { Not at } \\
\text { NZEF }\end{array}$ & \\
\hline Meetings held outside of award time & 3 & 46 & 13 & 9 & 71 \\
Meetings not held outside of award time & 3 & 5 & 16 & 6 & 30 \\
Not stated & 1 & 1 & 1 & 0 & 3 \\
Total & 7 & 52 & 30 & 15 & 104 \\
\hline
\end{tabular}

Table 6: Frequency of filing counter-claims

\begin{tabular}{lcccccrr}
\hline \multirow{2}{*}{ Frequency } & \multicolumn{2}{c}{ Trade association } & & Not trade association & Total \\
\cline { 2 - 3 } & At NZEF & $\begin{array}{c}\text { Not at } \\
\text { NZEF }\end{array}$ & At NZEF & $\begin{array}{c}\text { Not at } \\
\text { NZEF }\end{array}$ & \\
\hline Always & 3 & 21 & 22 & 8 & 54 \\
Sometimes & 3 & 23 & 5 & 4 & 35 \\
Never & 0 & 8 & 0 & 2 & 10 \\
Not stated & 1 & 0 & 3 & 1 & 5 \\
Total & 7 & 52 & 30 & 15 & 104 \\
\hline
\end{tabular}


above, union meetings are frequently held as adjuncts to meeting of the trade association, or union business is added as a minor item to the agenda of the trade association. We find that perhaps a half of union membership meetings of bifunctional organisations are of this type while about a third of industrial or management committee meetings are held as adjuncts to meetings of the trade association executive. Nonetheless, by having even this limited forum for discussion of industrial relations issues, bifunctional organisations provide members and committee members with an opportunity to raise particular industrial relations concerns, especially pressing matters. This may not be an ideal situation, but as Tables 4 and 5 show, it is considerably better than that achieved by the employer unions attached to the NZEF. It is of course not surprising that NZEF staff do not hold regular membership and committee meetings outside award time. The negotiation of the award is the most important function of an employer organisation and, during the term of the award, NZEF staff are busy with their own responsibilities. In any event, the membership support for such meetings may not be great. But it shows, yet again, how weakly organised New Zealand's employers are, and suggests that for any significant level of activity to occur it is desirable for an employer union to be bifunctional and to be separate from the NZEF, thus providing the framework for this activity.

Those employer unions who do hold meetings outside award time receive information that can serve as the basis for preparing a case for award negotiations. In the absence of such meetings during the currency of an award, employer unions are limited in their capacity to monitor the problems their members are experiencing with the award. This means that negotiating positions must be prepared quickly following meetings at award time. Given the pressure of time, it may not be possible to take full acount of members' problems. If so, the unions permanent staff and the industrial/management committee will dominate preparations for the award negotiations. For those unions with their office at the NZEF, the federation's staff rather than the membership will play the key role.

This is not to say that NZEF staff do not represent well the members of the unions which they organise. Although serving the particular union may be only one of a myriad of roles which the relevant NZEF staff member may be called to perform, he or she may bring to that job a range of relevant experience in industrial matters which may not be possessed by the secretary of a single-function or bifunctional union not attached to the NZEF.

\section{Counter claims}

An interesting perspective on the bargaining stance of differently organised unions is provided by Table 6 which shows the frequency with which the union, on receiving a log of claims from a worker union, will file a counter claim. We see from the table that unions located at the NZEF are more likely to file counter claims. Interestingly, bifunctional organisations are less likely to file counter claims. We find that 15 percent of bifunctional organisations located separately from the NZEF never file counter claims. In contrast, 73 percent of the single function unions at the NZEF always file counter claims and another 17 percent file them sometimes. Thus while bifunctional unions and/or independent unions show more activity outside award time, this appears to be offset by a less active stand in negotiations.

\section{Services}

Handling of negotiations is only one of a range of services which employer unions provide. The range of services offered is listed in Table 7. In general, employer unions tend to confine themselves to immediate industrial relations concerns. Advisory services are the most commonly provided, with approximately one half of employer unions giving advice beyond the services offered by the NZEF. One third further assist in the operation of dispute machinery and a slightly lesser number represent members before tribunals 
Table 7: Services provided to members

\begin{tabular}{|c|c|c|c|c|c|c|c|}
\hline Service & $\begin{array}{l}\text { Office at } \\
\text { NZEF }\end{array}$ & $\begin{array}{l}\text { Office not } \\
\text { at NZEF }\end{array}$ & $\begin{array}{l}\text { Office at } \\
\text { trade } \\
\text { association }\end{array}$ & $\begin{array}{l}\text { Office not } \\
\text { at trade } \\
\text { association }\end{array}$ & IAOE & IUOE & Total \\
\hline General advice & 7 & 42 & 34 & 15 & 8 & 41 & 49 \\
\hline Legal advice & 3 & 32 & 27 & 8 & 8 & 27 & 35 \\
\hline $\begin{array}{l}\text { Operation of dispute } \\
\text { machinery }\end{array}$ & 4 & 31 & 26 & 9 & 7 & 28 & 35 \\
\hline $\begin{array}{l}\text { Industrial relations } \\
\text { advice }\end{array}$ & 3 & 29 & 23 & 9 & 8 & 24 & 32 \\
\hline $\begin{array}{l}\text { Representative of members } \\
\text { before Arbitration Court, } \\
\text { Human Rights Commission, } \\
\text { etc. }\end{array}$ & 2 & 27 & 23 & 6 & 6 & 23 & 29 \\
\hline Apprenticeship matters & 7 & 21 & 19 & 9 & 7 & 21 & 28 \\
\hline $\begin{array}{l}\text { Assessment of manpower } \\
\text { requirements }\end{array}$ & 7 & 15 & 15 & 7 & 7 & 15 & 22 \\
\hline Safety services & 3 & 15 & 13 & 5 & 6 & 12 & 18 \\
\hline Training & 4 & 14 & 15 & 3 & 7 & 11 & 18 \\
\hline Other & 1 & 21 & 17 & 5 & 2 & 20 & 22 \\
\hline Total & 37 & 67 & 59 & 45 & 13 & 91 & 104 \\
\hline
\end{tabular}

or courts. About one quarter assist with apprenticeship issues and manpower needs, while less than 1 in 5 provide safety services or training. Few provide services, such as publications, beyond those listed in Table 7. If we bear in mind that only a proportion of the employer unions deal with apprenticeships at all, the administration of apprenticeships is probably the major function for those unions whose members employ apprentices.

These figures show precisely how moribund New Zealand's employer organisations are. It may be that the level of activity is even lower than Table 7 suggests, since due to misinterpretation of the question which asked about services additional to those of the NZEF, there may be some incidence of over reporting by our respondents. Certainly we are confident there is no more activity than the level recorded here. Gladstone argues that the provision of services is a "prime reason" why firms belong to employer organisations and, with the growing complexity of industrial relations, members have even more need for those services than they did in the past (Gladstone, 1984, p. 30). But, as we saw in Table 7 , in the main, New Zealand's employer unions provide their members with a minimal level of service, and it is unlikely that the level of service provided is an important consideration weighing in a firm's decision to join or to continue as a member. The principal factor in membership decisions is almost certainly the employer union's role in award negotiation.

Furthermore, the large firm may well have very little need of the services provided by employer organisations. Most major companies in New Zealand have their own personnel and/or industrial relations department, and prefer to rely upon their own staff for the services which they might otherwise seek from an employer organisation. In addition, many such companies have negotiated their own collective agreements with the various unions representing their different groups of workers. The administration of these agreements is entirely in the hands of company staff and the employer organisations have no role to play in this. Indeed, Gladstone notes that in other countries, many mediumsized and some small companies are developing a competence in this area to match the longstanding competence of large firms (Gladstone, 1984, p. 30). 


\section{Brosnan, Walsh and Rowe}

However, the personnel function is poorly developed in small New Zealand companies and perhaps in a majority of medium-sized companies. Certainly, only a small minority would be sufficiently well-developed as to be able to perform the range of services noted in Table 7. Thus, they depend upon their employer union or the NZEF for the provision of these services. It is clear from Table 7 that a great many firms receive very little service from their employer union. It seems, for example, quite remarkable that only one half provide any advisory services at all to their members, while less than one third claim to offer advice dealing specifically with industrial relations.

This fact may have made an important contribution to the quality of industrial relations in New Zealand. Worker unions are constantly exhorted to improve their delivery of services to their members. It is argued that if worker unions did this, then New Zealand's industrial relations would also improve. Indeed, this was one of the major justifications advanced by the National Party Government in 1983 for the introduction of voluntary unionism (Bolger, 1983). The Government claimed that once unions were no longer guaranteed their membership and revenues, they would have to service their memberhsip considerably better than in the past so as to recruit and retain members.

If the evidence presented here from the employer side is anything to go by, voluntary unionism goes with a rather poor provision of services to members. In fact, one IUOE wrote a lengthy and very strongly worded statement on this very issue on the back of the questionnaire. The view of this union was that membership of employer unions should be compulsory and they were rather resentful of the cold reception they claimed to have got when they raised the issue with the NZEF.

Size of the employer union is also an important factor and we note that a union is more likely to offer extra services if it is a bifunctional union and/or an IAOE than if it is single-function union or an IUOE. A further factor is whether or not the union is located at the NZEF.

It is plain from Table 7 that members of employer organisations based at the NZEF receive the lowest level of services from their own union. In one sense, however, this is slightly misleading in that for some services (e.g. operation of dispute machinery, representation of members before courts and tribunals), it may be unnecessary to provide any service beyond that already provided by the NZEF. But for some other services, especially the range of advisory services, members may be disadvantaged by not receiving assistance or advice specific to the industry or occupation concerned. And, as we noted with regard to the frequency of meetings, it is not surprising that NZEF-based organisations offer the lowest level of services. As a practical matter, it is difficult for NZEF staff to be very active in providing additional services to the members of individual unions. The traditional resistance of the NZEF to the development of industrial relations services being provided by trade associations (Rudman, 1974, p. 67) has thus not been overly successful but, more than that, it may have led to a less satisfactory level of advice for a proportion of the membership of employer unions.

\section{Conclusion}

The results of our 2 surveys of registered IUOEs and IAOEs has revealed how moribund the majority of employer unions are. Many were found to be completely inactive and even those that were active reported low levels of activity. It was clear in some cases that the secretaries of the unions were barely aware of their position and confused the union with an associated trade association. Such activity as some of these unions displayed tended to be associated with trade matters or apprenticeships rather than industrial matters per se. These findings confirm Rudman's earlier claims that most have been formed solely to enable employers "to become applicants in a dispute, and thereby maintain the national coverage of an award ... and . . they are for all intents and purposes 'legal fictions' " (Rudman, 1974, p. 68-69).

The second survey concentrated on the more active unions - IAOEs and IUOEs 
without an IAOE affiliation. Although nearly all these engaged in bargaining, we found that only one half held membership meetings outside of award time and that 30 percent did not even have their management or industrial committees meet outside award time. Such meetings as were held were sometimes simultaneous to, or tagged onto the end of, a trade association meeting. The provision of services beyond those provided by the New Zealand Employers Federation was also found to be very limited.

The focal role of the NZEF is an interesting one. One third of all IAOEs and unaffiliated IUOEs are located at the NZEF and all but a handful of employer unions draw on the NZEF's advocacy services. NZEF-based unions on the whole, though, are less active. They are less likely to have meetings and to provide additional services. On the other hand, they are more likely to make counter claims as part of the negotiation process. It would appear that handing the secretaryship of the union to the NZEF, while going with a lower membership involvement, means a more professional service and a more aggressive bargaining stance.

More than one half of employer unions are attached to trade associations, bifunctional unions, and it was clear that these unions display the highest levels of activity. Trade associations provide a financial and administrative base for a union and are able to provide specialised services beyond those of the NZEF. Although a few bifunctional unions are located at the NZEF, most are not and still represent the majority of unions. These unions do have strong links to the NZEF, though, since NZEF advocates act for virtually all of them in negotiations.

Many employers may see the NZEF's dominance of employer bargaining as a good thing but the price may be a lower level of activity among employer unions than ought to be the case. The inactivity among employer unions which this study has reported is partly due to the provisions of the Industrial Relations Act which encourage the formation and continued existence of employer unions but, at the same time, restrict their roles and range of services to members; but it is also due to the dominance of the NZEF which spoonfeeds many employer unions. If employer unions were to become more active we may see more realistic bargaining and better industrial relations. The current institutional arrangements make such a transition an unlikely development.

\section{References}

Batstone E, Boraston I and Frenkel S (1977) Shop stewards in action : the organisation of workplace conflict and accommodation Oxford, Blackwell.

Batstone E, Boraston I and Frenkel S (1978) The social organisation of strikes Oxford, Blackwell.

Batstone E, Ferner A and Terry M (1983) Unions on the board Oxford, Blackwell.

Bolger J B (1983) Reasons for voluntary unionism in 1983. In Brosnan P (Ed.) Voluntary unionism Industrial Relations Centre Seminar Proceedings, Victoria University of Wellington.

Brannen P, Batstone E, Fatchett D and White P (1976) The worker directors : a sociology of participation London, Hutchinson.

Brown W (Ed.) (1981) The changing contours of British industrial relations Oxford, Blackwell.

Bullock A (1977) Committee of inquiry on industrial democracy. Report. Cmnd 6706 London, HMSO.

Cappelli P (1985) Theory construction in IR and some implications for research Industrial relations, 24 (1) : 90-112.

Chiplin B (1977) Can workers manage? London, Institute of Economic Affairs. 
Clegg H (1976) Trade unionism under collective bargaining Oxford, Blackwell.

Department of Labour (1985) Annual report Wellington, Government Printer.

Donovan (1968) Report of the Royal Commission on trade unions and employer associations Cmnd 3623 London, HMSO.

Edwards P and Scullion H (1982) The social organisation of industrial conflict Oxford, Blackwell.

Gladstone A (1984) Employers associations in compartive perspective : functions and activities. In Windmuller $\mathrm{J}$ and Gladstone $\mathrm{A}$ (Eds) Employer associations and industrial relations Oxford, Clarendon Press.

Jackson P and Sisson K (1976) Employers confederations in Sweden and the UK and the significance of industrial infrastructure British journal of industrial relations 14 : 306-23.

Kochan T, McKersie R and Cappelli P (1984) Strategic choice and industrial relations theory Industrial relations 23 (1) : 16-39.

McCarthy W and Ellis N (1973) Management by agreement London, Hutchinson.

Moran M (1977) The politics of industrial relations London, Macmillan.

Plowman D (1978) Employer associations : challenges and responses Journal of industrial relations 20 (3) : 237-63.

Purcell J (1981) Good industrial relations : theory and practice London, Macmillan.

Purcell J (1983) The management of industrial relations in the modern corporation : agenda for research British journal of industrial relations 21 (1) : 1-16.

Rudman R (1974) Employer organisations : their development and role in industrial relations. In Howells $\mathrm{J} \mathrm{M}$ et al. (Eds) Labour and industrial relations in New Zealand Carlton, Pitman.

Sisson K (1983) The management of collective bargaining Oxford, Blackwell.

Thurley K and Wood S (1983) Industrial relations and management strategy Cambridge University Press.

Timperley S (1980) Organisation strategies and industrial relations Industrial relations journal $11(5): 38-45$.

Walsh P and McMaster F (1980) Crisis and confrontation : the origins of the 1979 General Strike Part 1 Industrial relations review 1 (5) : 33-39 and Part 21 (6) : 20-23.

Walsh P (1984a) The rejection of corporatism : trade unions, employers and the state in New Zealand, 1960-77 PhD thesis, University of Minnesota.

Walsh P (1984b) In recognition of skill : the growth of qualification payments New Zealand journal of industrial relations 9 (2) : 81-93.

Winchester D (1983) Industrial relations research in Britain British journal of industrial relations 21 (1) : 100-114.

Windmuller J (1984) Employers associations in comparative perspective : organisation, structure, administration. In Windmuller J and Gladstone A (Eds) Employers associations and industrial relations Oxford, Clarendon Press.

Wood S (1982) The study of management in British industrial relations Industrial relations journal 13 (2) : 51-61. 